\title{
ANALISIS TINGKAT KESEHATAN BANK DENGAN PENERAPAN METODE RGEC (RISK PROFILE, GOOD CORPORATE GOVERNANCE, EARNINGS DAN CAPITAL) PADA PT.BANK BENGKULU
}

\author{
Yun Fitriano \\ Ririn Marlina Sofyan \\ Fakultas Ekonomi Universitas Dehasen Bengkulu \\ yun.fitriano@gmail.com
}

\begin{abstract}
This study aims to determine the health level of PT. Bank Bengkulu in the 2014-2016 period if measured using the RGEC method (Risk Profile, Good Corporate Governance, Earnings, and Capital). Based on the results of the assessment of bank soundness by applying the RGEC method at PT. Bank Bengkulu is seen from factors, namely 1. Risk Profile, the results of the 2014 NPL ratio of $0.39 \%$, in 2015 amounted to $0.39 \%$, and in 2016 amounting to $0.33 \%$ can be said to be very healthy. The results of the LDR ratio in 2014 amounted to $85.79 \%$, in 2015 amounted to 91.05\%, and in 2016 amounting to 93.31\% this could be said to be quite healthy. 2. Good Corporate Governance in the 2014-2016 period of $89.33 \%$ can be said to be very healthy. 3. Eanings, the results of the 2014 ROA ratio amounted to 3.69\%, in 2015 amounted to 3.29\%, and in 2016 amounting to $3.02 \%$ this could be said to be very healthy. The results of the BOPO ratio in 2014 amounted to $74.10 \%$, in 2015 amounted to 80.54\%, and in 2016 amounting to $77.71 \%$ this could be said to be very healthy. 4. Capital, the results of the 2014 CAR ratio amounted to 16.99\%, in 2015 amounted to 21.39\%, and in 2016 amounting to $19.07 \%$ can be said to be very healthy. The results of the health research at PT. Bank Bengkulu in the 2014-2016 period showed that PT. The Bengkulu Bank gets PK 1, which is very healthy.
\end{abstract}

Keywords: Bank Health Level, RGEC Method, Bank Bengkulu 


\section{PENDAHULUAN}

Pada pertumbuhan ekonomi, sektor perbankan berperan aktif dalam menunjang kegiatan pembagunan ekonomi suatu Negara. Perbankan merupakan suatu roda perekonomian Indonesia, dimana perbankan berperan sebagai penghimpun, penyalur, dan pelayanan jasa dalam lalu lintas pembayaran dan peredaran uang di masyarakat. Perbankan bertujuan untuk menunjang pelaksanaan pembangunan nasional atau regional, dalam rangka meningkatkan pemerataan, pertumbuhan ekonomi, dan stabilitas nasional kearah peningkatan tarif sejahtera masyarakat kearah yang lebih baik.

Berdasarkan UU No. 7 Tahun 1992 tentang Perbankan sebagaimana telah diubah dengan UU No. 10 Tahun 1998 Perbankan adalah badan usaha yang menghimpun dana dari masyarakat dalam bentuk simpanan dan menyalurkannya kepada masyarakat dalam bentuk kredit atau bentuk-bentuk lainnya dalam rangka meningkatkan taraf hidup rakyat banyak.

Krisis perbankan sewaktu-waktu bisa kapan saja terjadi, oleh karena itu perbankan perlu menerapkan prinsip kehatian-hatian (Prudent Banking Principle) dalam menjaga dana masyarakat atau nasabah. Mengingat dana nasabah merupakan salah satu modal usaha dalam kegiatan operasional bank. Selain itu masyarakat atau nasabah bisa kapan saja menarik dana secara besar-besaran (bank runs) akibat ketidakpercayaan masyarakat atau nasabah terhadap bank. Menurut Kuncoro dan Suhardjono (2011:494) kepercayaan nasabah terhadap bank merupakan faktor yang sangat membantu dan mempermudah pihak manajemen bank untuk menyusun strategi bisnis yang baik.

Perbankan diwajibkan untuk selalu memelihara atau meningkatkan tingkat kesehatan bank dengan menerapkan prinsip kehatian-hatian dan manajemen risiko dalam melaksanakan kegiatan usaha. Menurut Budisantoso dan Nuritmo (2014:73) kesehatan bank merupakan kemampuan suatu bank untuk melakukan kegiatan operasional perbankan secara normal dan mampu memenuhi semua kewajibannya dengan baik yang sesuai dengan peraturan perbankan yang berlaku. Kesehatan perbankan harus dipelihara atau ditingkatkan agar kepercayaan masyarakat terhadap bank tetap terjaga. Selain itu, tingkat kesehatan bank digunakan sebagai salah satu tolak ukur dalam kondisi kesehatan kinerja keuangan bank dan permasalah yang dihadapi oleh bank itu sendiri.

Sekarang ini minat masyarakat kota Bengkulu terhadap dunia perbankan semakin tinggi, dimana salah satunya adalah PT. Bank Bengkulu yang dilandasi oleh unsur kepercayaan. Masyarakat percaya bahwa dananya tidak akan disalah gunakan oleh bank dan akan dikelola dengan baik. Agar mendapat kepercayaan masyarakat kota Bengkulu, penilaian tingkat kesehatan bank dirasa perlu dilakukan oleh PT. Bank Bengkulu. Penilaian tingkat kesehatan bank dilakukan untuk mengetahui apakah PT. Bank Bengkulu dalam kondisi tingkat kesehatan bank yang sangat sehat, sehat, cukup 
sehat, kurang sehat, dan tidak sehat. Akan tetapi, sebagian masyarakat tidak mengetahui kinerja keuangan atau tingkat kesehatan bank. Masyarakat hanya mengetahui pelayanan jasa perbankan saja. Hal tersebut bisa terjadi karena tingkat kesehatan bank atas perkembangan kinerja perbankan nasional hanya diketahui oleh dewan direksi, komisaris, divisi-divisi terkait, karyawan, dan Bank Indonesia (BI) saja. Masyarakat awam hanya bisa beropini apakah bank tersebut baik atau tidak dari segi kualitas pelayanan yang diterima dan menggangap sebuah bank kurang baik jika bank tersebut mendapat reputasi atau persepsi negatif dari media masa tanpa mengetahui secara pasti bagaimana kinerja keuangan dari kegiatan operasionalnya.

Bank Indonesia (BI) selaku Bank Sentral Indonesia telah menetapkan peraturan tentang tingkat kesehatan bank umum yang diatur dalam PBI No. 13/1/PBI/2011 tetang Penilaian Tingkat Kesehatan Bank Umum menggantikan PBI sebelumnya No. 6/10/PBI/2004 Sistem Penilaian Tingkat Kesehatan Bank Umum, yang dikenal dengan metode CAMELS (Capital, Asset quality, Managemen, Earnings, Liquidity dan Sensitivity to market risk). Berdasarkan PBI No. 13/1/PBI/2011 tanggal 5 Januari 2011 tentang Penilaian Tingkat Kesehatan Bank Umum, yaitu dengan menggunakan pendekatan Risiko (Risk-based bank Rating/RBBR) baik secara individual maupun secara konsolidasi, yaitu cakupan penilaian meliputi faktor-faktor sebagai berikut : Profil Risiko (risk profile), Good Corporate Governance (GCG), Rentabilitas (earnings), dan Permodalan (capital) atau yang dikenal sebagai metode RGEC. Metode RGEC ini merupakan penilaian terhadap risiko inheren dan kualitas penerapan manajemen risiko dalam operasi bank yang dilakukan terhadap 8 (delapan) risiko yaitu : risiko kredit, risiko pasar, risiko likuiditas, risiko operasional, risiko hukum, risiko stratejik, risiko kepatuhan, dan risiko reputasi.

PT. Bank Bengkulu merupakan bank pembangunan daerah kota Bengkulu yang berkantor pusat di Kota Bengkulu yang mempunyai visi dan misi untuk menjadi bank yang berkinerja tinggi dan menciptakan nilai tambah bagi masyarakat daerah Bengkulu serta menjadi bank yang diperhitungkan di Bengkulu. Selain itu PT. Bank Bengkulu baru saja meraih penghargaan Top BUMD tahun 2018 dengan meraih 2 (dua) penghargaan. Sesuai dengan visi dan misinya, maka PT. Bank Bengkulu dituntut untuk selalu meningkatkan nilai kesehatan bank agar masyarakat kota Bengkulu dapat meningkatkan kepercayaan dan minatnya dalam menyimpan dana sebagai nasabah di PT. Bank Bengkulu.

\section{TINJAUAN PUSTAKA}

Bank

Menurut Kasmir (2010:2), secara sederhana bank dapat diartikan sebagai lembaga keuangan yang kegiatan usahanya adalah menghimpun dana dari masyarakat dan menyalurkan kembali dana tersebut ke masyarakat serta memberikan jasa-jasa bank lainnya. Fungsi bank menurut Budisantoso dan Nuritmo (2014:9), fungsi utama bank 
adalah menghimpun dana dari masyarakat dan menyalurkan kembali kepada masyarakat untuk berbagai tujuan atau sebagai financial intermediary. Secara spesifik bank dapat berfungsi sebagai

1. Agent of trust, Dasar utama kegiatan perbankan adalah kepercayaan. Masyarakat akan mau menitipkan dananya di bank karena adanya kepercayaan. Pihak bank juga akan menyalurkan dananya kepada debitur karena adanya unsur kepercayaan.

2. Agent of development, Kegiatan bank yang berupa mengimpun dan menyalurkan dana. Kegiatan bank tersebut memungkinkan masyarakat melakukan kegiatan investasi, kegiatan distribusi, serta kegiatan konsumsi barang dan jasa. Kelancaraan kegiatan investasi-distribusi-konsumsi adalah kegiatan pembangunan perekonomian suatu masyarakat.

3. Agent of services, Bank memberikan penawaran jasa perbankan lain, seperti jasa pengiriman uang, penitipan barang berharga, pemberian jaminan bank, dan penyelesaian tagihan.

\section{Kesehatan Bank}

Menurut Budisantoso dan Nuritmo (2014:73), kesehatan bank adalah kemampuan suatu bank untuk melakukan kegiatan operasional perbankan secara normal dan mampu memenuhi semua kewajibannya dengan baik dengan cara-cara yang sesuai dengan peraturan perbankan yang berlaku. Berdasarkan pasal 29 UU No. 7 Tahun 1992 sebagaimana telah diubah dengan UU No. 10 Tahun 1998 Tentang Perbankan, bank wajib memelihara tingkat kesehatannya sesuai dengan ketentuan kecukupan modal, kualitas aset, kualitas manajemen, likuiditas, rentabilitas dan solvabilitas, serta aspek lain yang berkaitan dengan usaha bank dan wajib melakukan kegiatan usaha sesuai dengan prinsip kehatian-hatian.

Berdasarkan PBI No. 13/1/PBI/2011, bank diwajibkan untuk melakukan penilaian sendiri (self assessment) Tingkat Kesehatan Bank dengan menggunakan pendekatan Risiko (Risk-based Bank Rating/RBBR) baik secara individual maupun secara konsolidasi, dengan cakupan penilaian meliputi faktor-faktor sebagai berikut : Profil Risiko (risk profile), Good Corporate Governance (GCG), Rentabilitas (earnings), dan Permodaln (capital) untuk menghasilkan Peringkat Komposit Tingkat Kesehatan Bank.

\section{Metode RGEC}

Penilaian terhadap faktor-faktor RGEC adalah sebagai berikut :

1. Profil risiko (risk profile) 
Profil risiko adalah gambaran keseluruhan risiko yang melekat pada operasional bank. Penilaian faktor risk profile dilakukan penilaian teradap risiko inheren dan kualitas penerapan manajemen risiko, dalam kegiatan operasiaonal bank terhadap 8 (delapan) risiko, yaitu :

a. Risiko Kredit

Risiko kredit adalah risiko akibat kegagalan debitur dan atau pihak lain dalam memenui kewajiban kepada bank. Risiko kredit pada umumnya terdapat pada seluruh aktivitas bank yang kinerjanya bergantung pada kinerja pihak lawan (counterparty), penerbit (issuer), atau kinerja peminjam dana (borrower).

Rasio kredit dihitung dengan menggunakan rasio Non Performing Loan (NPL). Non Performing Loan (NPL) merupakan rasio yang digunakan untuk menghitung persentase jumlah kredit yang bermasalah yang dihadapi oleh bank. NPL dapat dirumuskan sebagai berikut :

NPL $=\frac{\text { Kredit Bermasalah }}{\text { Total Kredit }} \times 100 \%$

Kredit bermasalah adalah seluruh kredit pada puhak ketiga bukan bank dengan kolektibilitas kurang lancar, diragukan, dan macet. Total kredit adalah kredit pada pihak ketiga bukan bank.

b. Risiko pasar

Risiko pasar adalah risiko pada posisi neraca dan rekening administrative termasuk transaksi derivatif, akibat perubahan harga option.

c. Risiko likuiditas

Risiko likuiditas adalah risiko akibat ketidakmampuan bank untuk memenuhi kewajiban yang jatuh tempo dari sumber pendanaan arus kas, dan atau dari aset likuid berkualitas tinggi yang dapat diagunkan, tanpa menggangu aktivitas dan kondisi keuangan bank. Rasio likuiditas dihitung dengan menggunakan rasio Loan to Deposit Ratio (LDR). Loan to Deposit Ratio (LDR) merupakan rasio yang digunakan untuk menilai tingkat likuiditas suatu bank, dengan cara membandingkan antara kredit yang disalurkan dengan dana yang dihimpun dari masyarakat sehingga dapat diketahui kemampuan bank dalam membayar kewajiban jangka pendeknya. LDR dapat dirumuskan sebagai berikut :

LDR $=\frac{\text { Total Kredit }}{\text { Dana Pihak Ketiga }} \times 100 \%$ 


\section{d. Risiko Operasional}

Risiko operasional adalah risiko akibat ketidakcukupan dana atau tidak berfungsinya proses internal, kesalahan manusia, kegagalan sistem, dan atau adanya kejadian eksternal yang mempengaruhi operasional bank.

e. Risiko hukum

Risiko hukum adalah risiko yang timbul akibat tuntutan hukum dan atau kelemahan aspek yuridis. Risiko ini juga dapat timbul antara lain karena ketiadaan peraturan perundang-undangan yang mendasari atau kelemahan perikatan, seperti tidak dipenuhinya syarat sahnya kontrak atau agunan yang tidak memadai.

f. Risiko strategis

Risiko strategis adalah risiko akibat ketidaktepatan bank dalam mengambil keputusan dan atau pelaksanaan suatu keputusan strategis serta kegagalan dalam mengantisipasi perubahan lingkungan bisnis.

g. Risiko kepatuhan

Risiko kepatuhan adalah risiko yang timbul akibat bank tidak mematuhi dan atau tidak melaksanakan peraturan perundang-undangan dan ketentuan yang berlaku.

h. Risiko reputasi

Risiko reputasi adalah risiko akibat menurunnya tingkat kepercayaan stakeholder yang bersumber dari persepsi negatif terhadap bank.

\section{Good Corporate Governance}

Penilaian faktor GCG merupakan penilaian terhadap kualitas manajemen bank atas pelaksanaan prinsip-prinsip GCG. Prinsip- prinsip GCG dan fokus penilaian terhadap pelaksanaan prinsip-prinsip GCG berpedoman pada ketentuan Bank Indonesia mengenai pelaksanaan GCG bagi bank umum dengan memperhatikan karakteristik dan kompleksitas usaha bank.Prinsip-prinsip tata kelola perusahaan yang baik (GCG) antara lain :
a. Akuntabilitas (Accountability)
b. Pertanggungjawaban (Responsibility)
c. Keterbukaan (Transparency)
d. Kewajaran (Fairness)
e. Kemandirian (Independency)

\section{Earnings}

Earnings adalah salah satu penilaian kesehatan bank dari sisi rentabilitas. Indikator penilaian rentabilitas adalah ROA (Return On Assets), dan BOPO ( Beban Operasional Terhadap Pendapatan Operasional). Komponen laba actual terhadap proyeksi anggaran dan kemampuan komponen laba dalam 
meningkatkan permodalan. Karakteristik bank dari sisi rentabilitas adalah kinerja bank dalam menghasilkan laba, kestabilan komponen-komponen laba dalam meningkatkan permodalan dan prospek laba dimasa depan.

Penilaian terhadap faktor earnings didasarkan pada rasio-rasio yaitu :

a. Return On Assets (ROA)

Return On Assets (ROA) merupakan rasio yang digunakan untuk mengukur kemampuan bank dalam memperoleh keuntungan bersih dikaitkan dengan pembayaran deviden. ROA dapat dirumuskan sebagai berikut :

$$
\mathrm{ROA}=\frac{\text { LabaSebelumPajak }}{\text { Total Asset }} \times 100 \%
$$

b. Beban Operasional Terhadap Pendapatan Operasional (BOPO)

Beban Operasional Terhadap Pendapatan Operasional (BOPO) merupakan rasio yang digunakan untuk mengukur tingkat efisien dan kemampuan bank dalam melakukan kegiatan operasinya. BOPO dapat dirumuskan sebagai berikut :

$$
\text { BOPO }=\frac{\text { Beban Operasional }}{\text { Pendapatan Operasional }} \times 100 \%
$$

\section{Capital}

Capital atau permodalan memiliki indikator antara lain rasio kecukupan modal dan kecukupan modal bank untuk mengantisipasi potensi kerugian sesuai profil risiko yang disertai dengan pengelolaan permodalan yang sangat kuat sesuai dengan karakteristik, skala usaha dan kompleksitas usaha bank.

Rasio kecukupan modal :

$$
\mathrm{CAR}=\frac{\text { Modal }}{\text { Ativa Tertimbang Mengenai Risiko }} \times 100 \%
$$




\section{KERANGKA ANALISIS}

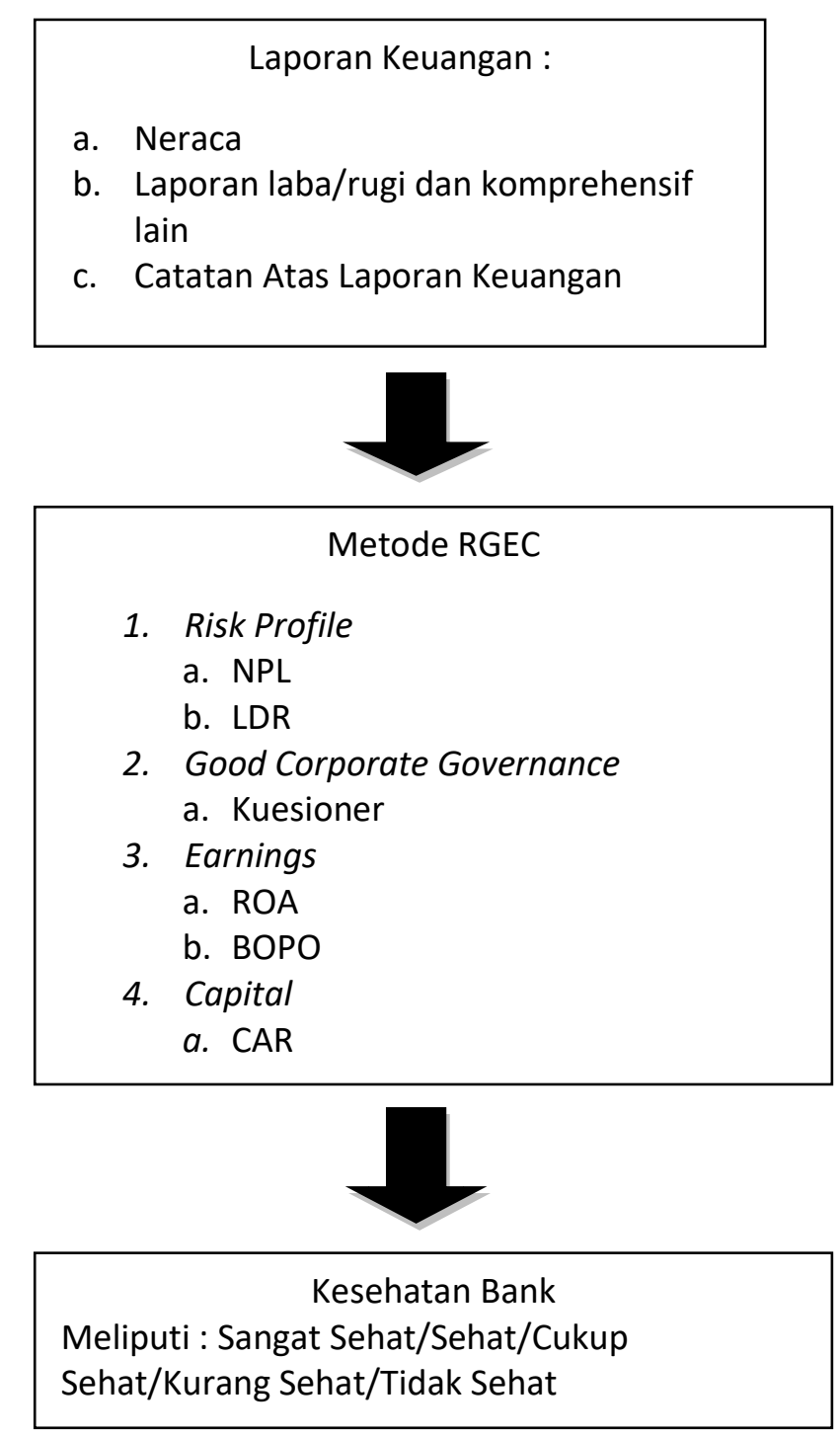

\section{Gambar 1. Kerangka Analisis Penelitian}

Metode Analisis.

\section{Risk Profile}

Risk profile merupakan penilaian terhadap kualitas penerapan manajemen risiko dalam aktivitas operasional bank. Dari 8 (delapan) risiko yang besar berpengaruh teradap operasional bank dalah Risiko Kredit dan Risiko Likuiditas dengan menggunakan rumus NPL dan LDR. 
a. Risiko Kredit

Dengan menghitung rasio Non Performing Loan :

NPL $=\frac{\text { Kredit Bermasalah }}{\text { Total Kredit }} \times 100 \%$

Tabel 1.

Matriks Kriteria Komponen Non Performing Loan

\begin{tabular}{|c|c|c|}
\hline Rasio NPL & Peringkat & Keterangan \\
\hline$<2 \%$ & 1 & Sangat sehat \\
\hline $2 \%-5 \%$ & 2 & Sehat \\
\hline $5 \%-8 \%$ & 3 & Cukup sehat \\
\hline $8 \%-12 \%$ & 4 & Kurang sehat \\
\hline$\geq 12 \%$ & 5 & Tidak sehat \\
\hline
\end{tabular}

Sumber : SE BI No. 13/24/DPNP tanggal 25 Oktober 2011

b. Risiko Likuiditas

Dengan menghitung Loan to Deposit Ratio :

LDR $=\frac{\text { Total Kredit }}{\text { Dana Pihak Ketiga }} \times 100 \%$

Tabel 2

Matriks Kriteria Komponen Loan to Deposit Ratio

\begin{tabular}{lcl}
\hline \multicolumn{1}{c}{ Rasio LDR } & Peringkat & \multicolumn{1}{c}{ Keterangan } \\
\hline$\leq 75 \%$ & 1 & Sangat sehat \\
\hline $75 \%-85 \%$ & 2 & Sehat \\
\hline $85 \%-100 \%$ & 3 & Cukup sehat \\
\hline $100 \%-120 \%$ & 4 & Kurang sehat \\
\hline$>120 \%$ & 5 & Tidak sehat \\
\hline
\end{tabular}

Sumber : SE BI No. 13/24/DPNP tanggal 25 Oktober 2011

\section{Good Corporate Governance}

Penilaian faktor GCG merupakan penilaian terhadap kualitas manajemen bank atas pelaksanaan prinsip-prinsip GCG. Prinsip-prinsip GCG dan fokus penilaian teradap pelaksanaan prinsip-prinsip GCG berpedoman pada ketentuan Bank Indonesia mengenai pelaksanaan GCG bagi bank umum dengan memperhatikan karakteristik dan kompleksitas usaha bank. Penelitian ini menggunakan kuesioner yang diberikan 
kepada responden PT. Bank Bengkulu dengan cara jumlah skor yang diperoleh dibagi dengan jumlah skor ideal (kreterium) untuk seluruh item (Sugiyono, 2013:169).

Tabel 3

Penetapan Peringkat Good Corporate Governance (GCG).

\begin{tabular}{ccc}
\hline Kriteria (\%) & Peringkat & Keterangan \\
\hline $81-100$ & 1 & Sangat sehat \\
\hline $61-80$ & 2 & Sehat \\
\hline $41-60$ & 3 & Cukup sehat \\
\hline $21-40$ & 4 & Kurang sehat \\
\hline $0-20$ & 5 & Tidak sehat \\
\hline
\end{tabular}

Sumber : Kodifikasi Peraturan Bank Indonesia

\section{Earnings}

Earnings adalah alat untuk menganalisis atau mengukur tingkat efisien usaha dan profibilitas yang dicapai oleh bank yang bersangkutan. Penilaian ini menggunakan rasio ROA dan BOPO, antara lain sebagai berikut :

a. Return On Asset (ROA)

$$
\mathrm{ROA}=\frac{\text { Laba Sebelum Pajak }}{\text { Total Asset }} \times 100 \%
$$

Tabel 4

Matriks Kriteria Komponen Return On Asset.

\begin{tabular}{lcc}
\hline Rasio ROA & Peringkat & Keterangan \\
\hline$>1,5 \%$ & 1 & Sangat sehat \\
\hline $1,25 \%-1,5 \%$ & 2 & Sehat \\
\hline $0,5 \%-1,25 \%$ & 3 & Cukup sehat \\
\hline $0 \%-0,5 \%$ & 4 & Kurang sehat \\
\hline$\leq 0 \%$ & 5 & Tidak sehat \\
\hline
\end{tabular}

Sumber : SE BI No. 13/24/DPNP tanggal 25 Oktober 2011

b. Beban Operasional Terhadap Pendapatan Operasional (BOPO)

$$
\text { BOPO }=\frac{\text { Beban Operasional }}{\text { Pendapatan Operasional }} \times 100 \%
$$


Tabel 5

Matriks Kriteria Komponen BOPO.

\begin{tabular}{lcc}
\hline Rasio BOPO & Peringkat & Keterangan \\
\hline$<83 \%$ & 1 & Sangat sehat \\
\hline $83 \%-85 \%$ & 2 & Sehat \\
\hline $85 \%-87 \%$ & 3 & Cukup sehat \\
\hline $87 \%-89 \%$ & 4 & Kurang sehat \\
\hline$\leq 89 \%$ & 5 & Tidak sehat \\
\hline
\end{tabular}

Sumber : SE BI No. 13/24/DPNP tanggal 25 Oktober 2011

2. Capital

Capital (permodalan) adalah metode penilaian bank berdasarkan permodalan yang dimiliki bank dengan menggunakan rasio Capital Adequacy Ratio (CAR).

$$
\mathrm{CAR}=\frac{\text { Modal }}{\text { Ativa Tertimbang Mengenai Risiko }} \times 100 \%
$$

Tabel 6

Matriks Kriteria Komponen Capital Adequacy Ratio .

\begin{tabular}{lcc}
\hline \multicolumn{1}{c}{ Rasio CAR } & Peringkat & Keterangan \\
\hline$\geq 12 \%$ & 1 & Sangat sehat \\
\hline $9 \%-15 \%$ & 2 & Sehat \\
\hline $8 \%-9 \%$ & 3 & Cukup sehat \\
\hline $6 \%-8 \%$ & 4 & Kurang sehat \\
\hline$<6 \%$ & 5 & Tidak sehat \\
\hline
\end{tabular}

Sumber : SE BI No. 13/24/DPNP tanggal 25 Oktober 2011

3. Penilai Peringkat Komposit Tingkat Kesehatan Bank

Peringkat komposit tingkat kesehatan bank PT. Bank Bengkulu dengan penerapan Metode RGEC secara keseluruhan.

Nilai komposit untuk rasio keuangan masing-masing komponen yang menempati peringkat komposit akan bernilai sebagai berikut :
a. Peringkat $1=$ dikalikan dengan 5
b. Peringkat 2 = dikalikan dengan 4
c. Peringkat $3=$ dikalikan dengan 3 
d. Peringkat $4=$ dikalikan dengan 2

e. Peringkat 5 = dikalikan dengan 1

Penerapan rumus untuk nilai komposit metode RGEC .

Nilai Komposit $=\frac{\text { Nilai Komposit Akrual }}{\text { Nilai Komposit Ideal }} \times 100 \%$

Tabel 7

Peringkat Komposit Tingkat Kesehatan Bank Dengan Penerapan Metode RGEC

\begin{tabular}{ccc}
\hline $\begin{array}{c}\text { Bobot } \\
\text { (\%) }\end{array}$ & Peringkat & Keterangan \\
\hline $86-100$ & PK 1 & Sangat sehat \\
\hline $71-85$ & PK 2 & Sehat \\
\hline $61-70$ & PK 3 & Cukup sehat \\
\hline $41-60$ & PK 4 & Kurang sehat \\
\hline$<40$ & PK 5 & Tidak sehat \\
\hline Sumber : SE BI No. 13/24/DPNP tanggal 25 Oktober 2011
\end{tabular}

\section{HASIL DAN PEMBAHASAN}

Hasil Analisis Tingkat Kesehatan Bank Dengan Penerapan Metode RGEC (Risk Profile, Good Corporate Governance, Earnings, dan Capital) Pada PT. Bank Bengkulu

1. Profil Risiko (Risk Profile)

a. NPL (Non Performing Loan)

NPL merupakan rasio yang digunakan untuk menghitung persentase jumlah kredit yang bermasalah yang dihadapi oleh bank. Kredit bermasalah adalah seluruh kredit pada pihak ketiga bukan bank dengan kolektibilitas kurang lancar, diragukan, dan macet. Total kredit adalah kredit pada pihak ketiga bukan bank. Menurut SE BI No. 13/24/DPNP tanggal 25 Oktober 2011 penggukuran NPL menggunakan :

NPL $=\frac{\text { Kredit Bermasalah }}{\text { Total Kredit }} \times 100 \%$

Tabel 8

Kredit Bermasalah PT. Bank Bengkulu Tahun 2014, 2015, dan 2016

(dalam jutaan rupiah)

\begin{tabular}{|c|c|c|c|}
\hline Keterangan & 2014 & 2015 & 2016 \\
\hline Kurang Lancar & 845 & 1.803 & 405 \\
\hline Diragukan & 2.535 & 1.794 & 1.632 \\
\hline Macet & 6.866 & 9.324 & 10.494 \\
\hline Jumlah Kredit Bermasalah & 10.246 & 12.921 & 12.531 \\
\hline
\end{tabular}

Sumber : Laporan Keuangan Tahun 2014, 2015, dan 2016. 
Tabel 9

Penilaian NPL PT. Bank Bengkulu tahun 2014, 2015, dan 2016

\begin{tabular}{cccccc}
\hline Tahun & $\begin{array}{c}\text { Kredit Bermasalah } \\
\text { (jutaan) }\end{array}$ & $\begin{array}{c}\text { Total Kredit } \\
\text { (jutaan) }\end{array}$ & NPL (\%) & PK & Keterangan \\
\hline 2014 & 10.246 & 2.595 .919 & 0,39 & 1 & Sangat Sehat \\
\hline 2015 & 12.921 & 3.282 .201 & 0,39 & 1 & Sangat Sehat \\
\hline 2016 & 12.531 & 3.742 .159 & 0,33 & 1 & Sangat Sehat \\
\hline
\end{tabular}

Sumber : Hasil Data Diolah tahun 2018

\section{b. LDR (Loan to Deposit Ratio)}

LDR merupakan rasio yang digunakan untuk menilai tingkat likuiditas suatu bank, dengan cara membandingkan antara kredit yang disalurkan dengan dana yang di himpun dari masyarakat sehingga dapat diketahui kemampuan bank dalam membayar kewajiban jangka pendeknya. Dana pihak ketiga adalah giro, tabungan, simpanan berkala, dan sertifikat deposito. Menurut SE BI No. 13/24/DPNP tanggal 25 Oktober 2011 penggukuran LDR menggunakan

LDR $=\frac{\text { Total Kredit }}{\text { Dana Pihak Ketiga }} \times 100 \%$

Tabel 10

Penilaian LDR PT. Bank Bengkulu Tahun 2014, 2015, dan 2016.

\begin{tabular}{cccccc}
\hline Tahun & Total Kredit (Rupiah) & $\begin{array}{c}\text { Dana Pihak Ketiga } \\
\text { (Rupiah) }\end{array}$ & $\begin{array}{c}\text { LDR } \\
\text { (\%) }\end{array}$ & PK & Keterangan \\
\hline 2014 & 2.595 .919 .344 & 3.025 .873 .843 & 85,79 & 3 & Cukup Sehat \\
\hline 2015 & 3.282 .201 .170 & 3.604 .617 .463 & 91,05 & 3 & Cukup Sehat \\
\hline 2016 & 3.742 .159 .172 & 4.010 .307 .158 & 93,31 & 3 & Cukup Sehat \\
\hline
\end{tabular}

Sumber : Hasil Data Diolah tahun 2018

\section{Good Corporate Governance (GCG)}

Sistem tata kelola yang baik menuntut pelaksanaan prinsip-prinsip GCG dalam proses manajeril bank. Dalam pengukuran Good Corporate Governance (GCG) ini dari penyebaran kuesioner pada nasabah dan karyawan PT. Bank Bengkulu diperoleh pernyataan responden mengenai implementasi prinsip-prinsip Good Corporate Governance (GCG) pada PT. Bank Bengkulu. Berdasarkan data-data yang telah dikumpulkan, maka tingkat Good Corporate Governance (GCG) pada PT. Bank Bengkulu dapat dihitung dengan cara sebagai berikut :

$$
\begin{aligned}
& \text { \% Skor Aktual }=\frac{\text { Skor Aktual }}{\text { Skor Ideal }} \times 100 \% \\
& =\frac{4.422}{30 \times 5 \times 33} \times 100 \%
\end{aligned}
$$




$$
\begin{aligned}
= & \frac{4.422}{4.950} \times 100 \% \\
= & 89,33 \% \rightarrow \text { Peringkat } 1 \rightarrow \text { Sangat Sehat }
\end{aligned}
$$

\section{Earnings (Rentabilitas)}

Earnings adalah penilaian dari sisi rentabilitas pada bank. Dengan menggunakan rasio ROA dan BOPO adalah sebagai berikut :

a. ROA (Return On Asset)

$$
\mathrm{ROA}=\frac{\text { Laba Sebelum Pajak }}{\text { Total Asset }} \times 100 \%
$$

Tabel 11

Penilaian ROA Tahun 2014, 2015, dan 2016

\begin{tabular}{cccccc}
\hline Tahun & $\begin{array}{c}\text { Laba Sebelum } \\
\text { pajak (Rupiah) }\end{array}$ & $\begin{array}{c}\text { Total Asset } \\
\text { (Rupiah) }\end{array}$ & $\begin{array}{c}\text { ROA } \\
\text { (\%) }\end{array}$ & PK & Ket \\
\hline 2014 & 145.029 .894 & 3.920 .719 .978 & 3,69 & 1 & Sangat Sehat \\
\hline 2015 & 151.613 .520 & 4.607 .038 .828 & 3,29 & 1 & Sangat Sehat \\
\hline 2016 & 155.469 .473 & 5.136 .647 .584 & 3,02 & 1 & Sangat Sehat \\
\hline
\end{tabular}

Sumber : Hasil Data Diolah Tahun 2018

b. BOPO (Biaya Operasional terhadap Pendapatan Operasional)

$$
\text { BOPO }=\frac{\text { Beban Operasional }}{\text { Pendapatan Operasional }} \times 100 \%
$$

Tabel 12

Penilaian BOPO tahun 2014, 2015, dan 2016

\begin{tabular}{cccccc}
\hline Tahun & $\begin{array}{c}\text { Beban Operasional } \\
\text { (Rupiah) }\end{array}$ & $\begin{array}{c}\text { Pendapatan } \\
\text { Operasional } \\
\text { (Rupiah) }\end{array}$ & $\begin{array}{c}\text { BOPO } \\
\text { (\%) }\end{array}$ & PK & Keterangan \\
\hline 2014 & 373.950 .544 & 504.605 .745 & 74,10 & 1 & Sangat Sehat \\
\hline 2015 & 505.883 .321 & 628.085 .914 & 80,54 & 1 & Sangat Sehat \\
\hline 2016 & 532.052 .757 & 684.602 .577 & 77,71 & 1 & Sangat Sehat \\
\hline
\end{tabular}

Sumber : Hasil Data Diolah Tahun 2018.

\section{Capital (Permodalan)}

Capital (permodalan) adalah metode penilaian bank berdasarkan permodalan yang dimiliki bank dengan menggunakan rasio Capital Adequacy Ratio (CAR). 


$$
\mathrm{CAR}=\frac{\text { Modal }}{\text { Ativa Tertimbang Mengenai Risiko }} \times 100 \%
$$

Tabel 13

Modal dan ATMR tahun 2014, 2015, dan 2016

\begin{tabular}{lrrr} 
& & & (dalam ribuan rupiah) \\
\hline \multicolumn{1}{c}{ Keterangan } & $\mathbf{2 0 1 4}$ & $\mathbf{2 0 1 5}$ & $\mathbf{2 0 1 6}$ \\
\hline Modal Inti & 278.599 & 438.244 & 512.027 \\
\hline Modal Perlengkap & 16.276 & 80.825 & 26.939 \\
\hline Jumlah Modal & 294.875 & 519.069 & 538.966 \\
\hline ATMR risiko kredit & 1.304 .493 & 1.837 .201 & 2.155 .095 \\
\hline ATMR risiko operasional & 430.198 & 589.338 & 669.947 \\
\hline Jumlah ATMR & 1.734 .691 & 2.426 .539 & 2.825 .042 \\
\hline
\end{tabular}

Sumber : Catatan Atas Laporan Keuangan Tahun 2014, 2015, dan 2016

Tabel 14

Penilaian CAR tahun 2014, 2015, dan 2016

\begin{tabular}{cccccc}
\hline Tahun & Modal Bank & ATMR & CAR (\%) & PK & Keterangan \\
\hline 2014 & 294.875 & 1.734 .691 & 16,99 & 1 & Sangat Sehat \\
\hline 2015 & 519.069 & 2.426 .539 & 21,39 & 1 & Sangat Sehat \\
\hline 2016 & 538.966 & 2.825 .042 & 19,07 & 1 & Sangat Sehat
\end{tabular}

Sumber : Hasil Data Diolah Tahun 2018

\section{Pembahasan}

Berdasarkan hasil penelitian yang telah dilakukan terhadap penilaian tingkat kesehatan PT. Bank Bengkulu dengan menggunakan metode RGEC (risk profile, Good Corporate Governance, earnings, dan capital) maka hasil dari penilaian tingkat kesehatan bank adalah sebagai berikut :

Tabel 15

Hasil Penilaian Tingkat Kesehatan PT. Bank Bengkulu Tahun 2014

\begin{tabular}{|c|c|c|c|c|c|c|c|c|}
\hline \multirow{2}{*}{ Tahun } & \multirow{2}{*}{\multicolumn{2}{|c|}{ Komponen RGEC }} & \multirow{2}{*}{ \% Rasio } & \multicolumn{5}{|c|}{ Peringkat } \\
\hline & & & & 1 & 2 & 3 & 4 & 5 \\
\hline \multirow{6}{*}{2014} & \multirow{2}{*}{ Risk Profile } & NPL & $0,39 \%$ & $\checkmark$ & & & & \\
\hline & & LDR & $85,79 \%$ & & & $\checkmark$ & & \\
\hline & GCG & Kuesioner & $89,33 \%$ & $\checkmark$ & & & & \\
\hline & \multirow{2}{*}{ Earnings } & ROA & $3,69 \%$ & $\checkmark$ & & & & \\
\hline & & BOPO & $74,10 \%$ & $\checkmark$ & & & & \\
\hline & Capital & CAR & $16,99 \%$ & $\checkmark$ & & & & \\
\hline \multicolumn{3}{|c|}{ Nilai Komposit RGEC } & \multicolumn{6}{|c|}{28} \\
\hline
\end{tabular}

Sumber : Hasil Data Diolah Tahun 2018

$$
\text { Nilai Komposit }=\frac{\text { Nilai Komposit Akrual }}{\text { Nilai Komposit Ideal }} \times 100 \%
$$




$$
=\frac{28}{30} \times 100 \%=93,33 \%
$$

Tabel 16

Peringkat Komposit Tingkat Kesehatan PT. Bank Bengkulu Tahun 2014

\begin{tabular}{cccc}
\hline Tahun & Nilai Komposit (\%) & Peringkat Metode RGEC & Keterangan \\
\hline 2014 & $93,33 \%$ & 1 & Sangat Sehat \\
\hline
\end{tabular}

Sumber : Hasil Data Diolah Tahun 2018

Apabila melihat tabel 18, bahwa peringkat faktor risk profile (Profil Risiko) pada PT. Bank Bengkulu tahun 2014 termasuk peringkat 2 dengan keterangan sehat karena hasil dari penilaian risiko kredit dan risiko likuiditas. Penilaian risiko kredit dengan rasio NPL sebesar $0,39 \%$ hal ini termasuk peringkat 1 dengan keterangan sangat sehat karena hasil rasio kurang dari ketetapan yang berlaku yaitu $<2 \%$. Penilaian risiko likuiditas dengan rasio LDR sebesar $85,79 \%$ hal ini termasuk peringkat 3 dengan keterangan cukup sehat karena hasil rasio lebih dari ketetapan yang berlaku yaitu < $85 \%$. Sehingga kemungkinan kerugian yang dihadapi bank dari risiko inheren tergolong rendah selama periode waktu tertentu dimasa yang akan datang dan kualitas penerapan manajemen risiko yang sehat.

Peringkat faktor good corporate governance (GCG) pada tingkat kesehatan PT. Bank Bengkulu tahun 2014 dengan penilaian kuesioner. Menunjukkan hasil dengan nilai $89,33 \%$ yang dapat diartikan bahwa secara umum good corporate governance (GCG) PT. Bank Bengkulu tergolong sangat sehat dengan kategori peringkat 1. Hal tersebut karena prinsip-prinsip good corporate governance (GCG) telah diimplementasikan dengan baik oleh PT, Bank Bengkulu dan dapat diselesaikan dengan tindakan yang sesuai dengan aturan yang telah berlaku.

Peringkat faktor earnings (Rentabilitas) pada PT. Bank Bengkulu tahun 2014 termasuk peringkat 1 dengan keterangan sangat sehat karena hasil dari penilaian rasio ROA dan BOPO. Penilaian rasio ROA sebesar 3,69\% hal ini termasuk peringkat 1 dengan keterangan sangat sehat karena hasil rasio lebih dari ketetapan yang berlaku yaitu > 1,5\%. Penilaian rasio BOPO sebesar $74,10 \%$ hal ini termasuk peringkat 1 dengan keterangan sangat sehat karena hasil rasio kurang dari ketetapan yang berlaku yaitu < 83\%. Sehingga dapat diartikan bawah PT. Bank Bengkulu memperoleh laba melebihi dari target yang telah ditentukan dan juga didukung oleh pemodalan yang baik.

Peringkat faktor capital (Permodalan) pada PT. Bank Bengkulu tahun 2014 termasuk peringkat 1 dengan keterangan sangat sehat karena rasio CAR sebesar $16,99 \%$ hal ini termasuk peringkat 1 dengan keterangan sangat sehat karena hasil rasio lebih dari ketetapan yang berlaku yaitu $>12 \%$. Sehingga dapat diartikan bawa PT. Bank Bengkulu memiliki kecukupan modal yang baik dan mampu menghadapi profil risikonya. 
Berdasarkan penilaian tingkat kesehatan PT. Bank Bengkulu tahun 2014 dengan menerapkan metode RGEC yang sudah sesuai dengan standar yang telah ditetapkan oleh Bank Indonesia berdasarkan SE BI No. 13/24/DPNP tanggal 25 oktober 2011 menunjukkan bahwa peringkat komposit 1 dengan keterangan sangat sehat, sehingga dinilai sangat mampu menghadapi pengaruh negatif yang signifikan dari perubahan kondisi bisnis dan faktor lainnya.

Tabel 17

Hasil Penilaian Tingkat Kesehatan PT. Bank Bengkulu Tahun 2015.

\begin{tabular}{|c|c|c|c|c|c|c|c|c|}
\hline \multirow{2}{*}{ Tahun } & \multirow{2}{*}{\multicolumn{2}{|c|}{ Komponen RGEC }} & \multirow{3}{*}{$\begin{array}{c}\text { \% Rasio } \\
0,39 \%\end{array}$} & \multicolumn{5}{|c|}{ Peringkat } \\
\hline & & & & 1 & 2 & 3 & 4 & 5 \\
\hline \multirow{6}{*}{2015} & \multirow{2}{*}{ Risk Profile } & NPL & & $\checkmark$ & & & & \\
\hline & & LDR & $91,05 \%$ & & & $\checkmark$ & & \\
\hline & GCG & Kuesioner & $89,33 \%$ & $\checkmark$ & & & & \\
\hline & \multirow{2}{*}{ Earnings } & ROA & $3,29 \%$ & $\checkmark$ & & & & \\
\hline & & BOPO & $80,54 \%$ & $\checkmark$ & & & & \\
\hline & Capital & CAR & $21,39 \%$ & $\checkmark$ & & & & \\
\hline
\end{tabular}

Sumber : Hasil Data Diolah Tahun 2018

Nilai Komposit $=\frac{\text { Nilai Komposit Akrual }}{\text { Nilai Komposit Ideal }} \times 100 \%$

$$
=\frac{28}{30} \times 100 \%=93,33 \%
$$

Tabel 18

Peringkat Komposit Tingkat Kesehatan PT. Bank Bengkulu Tahun 2015

\begin{tabular}{cccc}
\hline Tahun & Nilai Komposit (\%) & Peringkat Metode RGEC & Keterangan \\
\hline 2015 & $93,33 \%$ & 1 & Sangat Sehat \\
\hline
\end{tabular}

Sumber : Data Diola Peneliti Tahun 2018

\section{Kesimpulan}

Berdasarkan hasil penelitian dan pembahasan, maka dapat diambil kesimpulan:

1. Penilaian tingkat kesehatan PT. Bank Bengkulu pada periode tahun 2014-2016 dengan penerapan metode RGEC:

a. Risk profile (Profil Risiko)

Risk profile (Profil Risiko) hasil dari rasio NPL pada PT. Bank Bengkulu tahun 2014 sebesar 0,39\%, tahun 2015 sebesar 0,39\% dan tahun 2016 sebesar 0,33\% hal ini digolongkan peringkat 1 dengan keterangan sangat sehat karena hasil rasio kurang dari ketetapan yang berlaku yaitu $<2 \%$. Hasil dari rasio LDR pada PT. Bank Bengkulu tahun 2014 sebesar 85,79\%, tahun 2015 sebesar 91,05\%, dan tahun 
2016 sebesar 93,31\% hal ini termasuk peringkat 3 dengan keterangan cukup sehat karena hasil rasio lebih dari ketetapan yang berlaku yaitu $<85 \%$.

b. Good Corporate Governance (GCG)

Good Corporate Governance (GCG) pada PT. Bank Bengkulu dalam periode tahun 2014-2016 sebesar $89,33 \%$ hal ini termasuk kategori sangat sehat yaitu peringkat 1.

c. Earnings (Rentabilitas)

Earnings (Rentabilitas) hasil dari rasio ROA pada PT. Bank Bengkulu tahun 2014 sebesar 3,69\%, tahun 2015 sebesar 3,29\% dan tahun 2016 sebesar 3,02\% hal ini digolongkan peringkat 1 dengan keterangan sangat sehat karena hasil rasio lebih dari ketetapan yang berlaku yaitu $>1,5 \%$. Hasil dari rasio BOPO pada PT. Bank Bengkulu tahun 2014 sebesar 74,10\%, tahun 2015 sebesar 80,54\%, dan tahun 2016 sebesar $77,71 \%$ hal ini termasuk peringkat 1 dengan keterangan sangat sehat karena hasil rasio kurang dari ketetapan yang berlaku yaitu $<83 \%$.

d. Capital (Permodalan)

Capital (Permodalan) hasil dari rasio CAR pada PT. Bank Bengkulu tahun 2014 sebesar 16,99\%, tahun 2015 sebesar 21,39\%, dan tahun 2016 sebesar 19,07\% hal ini digolongkan peringkat 1 dengan keterangan sangat sehat karena hasil rasio lebih dari ketetapan yang berlaku yaitu > 12\%. Sehingga faktor Capital (Permodalan) termasuk peringkat 1 dengan keterangan sangat sehat.

2. Penilaian tingkat kesehatan bank dengan menerapkan metode RGEC pada PT. Bank Bengkulu untuk tahun 2014 diperoleh peringkat komposit 1 dengan keterangan “ Sangat Sehat", untuk tahun 2015 diperoleh peringkat komposit 1 dengan keterangan "Sangat Sehat", dan untuk tahun 2016 diperoleh peringkat komposit 1 dengan keterangan "Sangat Sehat". Hal ini mencerminkan kondisi bank pada PT. Bank Bengkulu periode tahun 2014-2016 yang secara umum " Sangat Sehat" sehingga dinilai "Sangat Mampu" menghadapi perngaruh negatif yang signifikan dari perubahan kondisi bisnis dan faktor eksternal lainnya.

\section{Saran}

1. Diharapkan PT. Bank Bengkulu tetap mempertahankan atau menjaga tingkat kesehatan dan kinerjanya guna untuk mempertahankan kepercayaan masyarakat, nasabah, karyawan, pemegang saham, dan juga pihak lainnya..

2. Dalam hal ini PT. Bank Bengkulu dapat meningkatkan dan memperhatikan faktor risiko likuiditas guna untuk meningkatkan nilai kepercayaan nasabah.

3. Bagi peneliti selanjutnya, disarankan untuk memperluas cakupan penelitian tentang penilaian tingkat kesehatan bank dengan menggunakan indikator rasio keuangan lainnya dan menggunakan metode terbaru sesuai dengan Surat Edaran Bank Indonesia selaku bank sentral. 


\section{DAFTAR PUSTAKA}

Arikunto. 2013. Prosedur Penelitian : Suatu Pendekatan Praktek. Jakarta : Rineka Cipta. Artyka, Nur. 2015. Penilaian Kesehatan Bank Dengan Metode RGEC Pada PT. Bank Rakyat Indonesia (Persero) Tbk Periode 2011-2013. Yogyakarta, Universitas Negeri Yogyakarta. (http://eprints.uny.ac.id/17380/1/SRIPSI\%20FULL.pdf)

Bank Indonesia, Peraturan Bank No.13/1/PBI/2011 Tentang Penilaian Tingkat Kesehatan Bank Umum.

Bank Indonesia, Surat Edaran No.13/24/DPNP Tanggal 25 Oktober 2011 PerihalTentang Penilaian Tingkat Kesehatan Bank Umum.

Bank Indonesia, Peraturan Bank No.6/10/PBI/2004 Sistem Penilaian Tingkat Kesehatan Bank Umum.

Budisantoso, Totok dan Nuritmo. 2014. Bank dan Lembaga Keuangan Lain. Jakarta : Salemba Empat.

Emilia. 2017. Analisis Tingkat Kesehatan Bank Dengan Metode RGEC (Risk Profile, Good Corporate Governance, Earnings, and Capital) Pada PT. Bank BNI Syariah. Palembang, Universitas Islam Negeri Raden Fatah Palembang.

(http://eprints.radenfatah.ac.id/1340/1/EMILIA\%20(14180072).pdf)

IBI. 2016. Manajemen Kesehatan Bank Berbasis Risiko. Jakarta : PT. Gramedia Pustaka Utama.

Kasmir. 2010. Bank dan Lembaga Keuangan Lainnya. Jakarta : PT. Raja Grafindo Persada.

Kasmir. 2013. Analisis Laporan Keuangan. Jakarta : PT. Raja Grafindo Persada

Kuncoro, Mudrajat dan Suhardjono.2011. Manajemen Perbankan Teori dan Aplikasi.Yogyakarta : BPFE

Sugiyono. 2013. Metode Penelitian Manajemen. Bandung : Alfabeta.

Sujarweni, Wiratna. 2017. Kupas Tuntas Penelitian Akuntansi Dengan SPSS.Yogjakarta : Pustaka Baru Pres

Sukmadinata, Nana Syaodih. 2009. Metode Penelitian Pendidikan. Bandung : PT. Remaja Rosdakarya.

Undang-Undang. 1998. Undang-Undang No.10 Tahun 1998 tentang perbankan. 